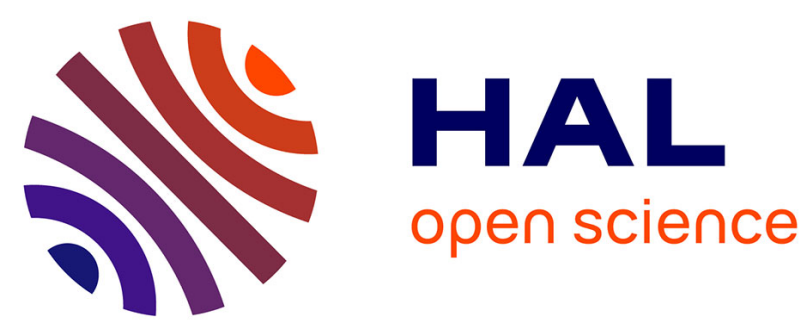

\title{
Major role of MT2 receptors in the beneficial effect of melatonin on long-term recognition memory in C57BL/6J male mice
}

Cristiana Pistono, Amandine Zimmermann, Chloé Morel, Karine Herbeaux, Céline Héraud, Stéphanie Dumont-Kientzy, Paul Pevet, Marie-Paule

Felder-Schmittbuhl, Chantal Mathis

\section{To cite this version:}

Cristiana Pistono, Amandine Zimmermann, Chloé Morel, Karine Herbeaux, Céline Héraud, et al.. Major role of MT2 receptors in the beneficial effect of melatonin on long-term recognition memory in C57BL/6J male mice. Hormones and Behavior, 2021, 136, pp.105076. 10.1016/j.yhbeh.2021.105076 . hal-03396198

\section{HAL Id: hal-03396198 https://hal.science/hal-03396198}

Submitted on 22 Oct 2021

HAL is a multi-disciplinary open access archive for the deposit and dissemination of scientific research documents, whether they are published or not. The documents may come from teaching and research institutions in France or abroad, or from public or private research centers.
L'archive ouverte pluridisciplinaire HAL, est destinée au dépôt et à la diffusion de documents scientifiques de niveau recherche, publiés ou non, émanant des établissements d'enseignement et de recherche français ou étrangers, des laboratoires publics ou privés. 
Title: Major role of MT2 receptors in the beneficial effect of melatonin on long-term recognition memory in C57BL/6J male mice

Cristiana Pistono ${ }^{1, \mathrm{a}}$, Amandine Zimmermann ${ }^{1}$, Chloé Morel $^{1}$, Karine Herbeaux ${ }^{1}$, Céline Héraud ${ }^{1}$, Stéphanie Dumont-Kientzy ${ }^{2}$, Paul Pevet ${ }^{2}$, Marie-Paule Felder-Schmittbuhl ${ }^{2}$, Chantal Mathis ${ }^{1}$

${ }^{1}$ Université de Strasbourg, CNRS UMR 7364, Laboratoire de Neurosciences Cognitives et Adaptatives (LNCA), 12 rue Goethe, Strasbourg, France

${ }^{2}$ Université de Strasbourg, Centre National de la Recherche Scientifique, Institut des Neurosciences Cellulaires et Intégratives, F-67000 Strasbourg, France.

${ }^{\text {a }}$ Present address: A.I.Virtanen Institute for Molecular Sciences, University of Eastern Finland, Neulaniementie 2, 70211 Kuopio, Finland.

\section{Corresponding author:}

Cristiana Pistono

A.I.Virtanen Institute for Molecular Sciences, University of Eastern Finland, Neulaniementie 2, 70211 Kuopio, Finland.

e-mail: pistono.cristiana@gmail.com

Abstract: Melatonin, a major signal of the circadian system, is also involved in brain functions such as learning and memory. Chronic melatonin treatment is known to improve memory performances, but the respective contribution of its central receptors, $\mathrm{MT}_{1}$ and $\mathrm{MT}_{2}$, is still unclear. Here, we used new single receptor deficient $\mathrm{MT}_{1}{ }^{-/}$and $\mathrm{MT}_{2}{ }^{-/}$mice to investigate the contribution of each receptor in the positive effect of chronic melatonin treatment on long-term recognition memory. The lack of $\mathrm{MT}_{2}$ receptor precluded memory-enhancing effect of melatonin in the object recognition task and to a lesser extent in the object location task, whereas the lack of $\mathrm{MT}_{1}$ receptor mitigated its effect in the object location task only. Our findings support a key role of $\mathrm{MT}_{2}$ in mediating melatonin's beneficial action on long-term object recognition memory, whereas $\mathrm{MT}_{1}$ may contribute to the effect on object location memory.

Keywords: melatonin; $\mathrm{MT}_{1}$ deficiency; $\mathrm{MT}_{2}$ deficiency; long-term recognition memory; object recognition; object location. 


\section{INTRODUCTION}

Melatonin regulates the circadian rhythms of several biological functions such as sleep or memory (Comai and Gobbi, 2014). Chronic administration of melatonin and its analogs has been proposed to have therapeutic potentials in brain diseases such as Alzheimer's disease (AD) (Shukla et al., 2017). Brain melatonin acts mainly through G-protein-coupled $\mathrm{MT}_{1}$ and $\mathrm{MT}_{2}$ receptors (Dubocovich et al., 2005). Clear differences in their neuroanatomic distribution suggest an involvement in distinct brain processes (Klosen et al., 2019; Lacoste et al., 2015). Restoring melatonin's levels affected by aging improves cognitive status in the elderly and in early stages of AD (Jean-Louis et al., 1998; Peck et al., 2004). Chronic melatonin supplementation in drinking water also had beneficial effect on cognition in rodent models of normal and pathological aging (Mukda et al., 2016; O'Neal-Moffitt et al., 2015). However, both pharmacological and genetic approaches have not yet provided a clear picture of the respective involvement of $\mathrm{MT}_{1}$ and $\mathrm{MT}_{2}$ in the positive effects of melatonin on learning and memory because most studies used $\mathrm{MT}_{1} / \mathrm{MT}_{2}$ double knock-out mice and mixed $\mathrm{MT}_{1} / \mathrm{MT}_{2}$ agonists (BertainaAnglade et al., 2011; He et al., 2013; O’Neal-Moffitt et al., 2014). In order to progress in therapeutic approaches based on melatonin analogs to improve memory disorders it is important to know the respective role of $\mathrm{MT}_{1}$ and $\mathrm{MT}_{2}$ receptors in memory processes. Here, we used single receptor- $\left(\mathrm{MT}_{1}^{-1-}\right.$ and $\mathrm{MT}_{2}^{-{ }^{-}}$) deficient mice created with a "knock-in" strategy to insert a LacZ reporter instead of the receptor coding sequences to determine whether these receptors are involved in recognition memory (Klosen et al., 2019). This form of memory is known to be affected in early stages of Alzheimer's disease (Mathis, 2018). We first confirmed that chronic melatonin treatment improves recognition memory performance in C57BL/6J (B6) mice tested in object recognition (OR) and object location (OL) tasks. Then, the treatment was given to $\mathrm{MT}_{1}^{-{ }^{--}}$and $\mathrm{MT}_{2}^{-{ }^{--}}$mice to determine the possible involvement of $\mathrm{MT}_{1}$ and/or $\mathrm{MT}_{2}$ in the memory-enhancing effect of melatonin.

\section{MATERIAL AND METHODS}

The B6 strain is well adapted to test the effects of exogenous melatonin because it produces very low amounts of melatonin with functional melatonin receptors (Dubocovich et al., 2005). The experiments were first conducted in male B6 mice (Charles River Laboratories, L'Arbresle, France) and then in $\mathrm{MT}_{1}{ }^{-}$ /- and $\mathrm{MT}_{2}^{-{ }^{-/}}$mice and their wild type (WT) littermates. The two lines were maintained separately on a B6 background (INCI, Strasbourg, France; see (Klosen et al., 2019)). Mice lived in cages with nesting material, food and water ad libitum, and under controlled temperature $\left(23^{\circ} \mathrm{C} \pm 1{ }^{\circ} \mathrm{C}\right)$ and light/dark cycle (12:12 hour lights on at 8.00 a.m.). Animal facilities of the LNCA (French Ministry of Agriculture and Food approval: H 67-482-13 and I 67-482-13) and procedures in compliance with the European Community Council Directive (2010/63UE) were approved by the local ethical committee and 
authorized by the French Ministry for Higher Education, Research and Innovation (APAFIS\#75452016111017234161.v2).

The effect of chronic melatonin treatment on recognition memory was first assessed in 12 6-month-old B6 males, and then in $\mathrm{MT}_{1}^{---}(n=13)$ and their WT $(n=12)$, and also $\mathrm{MT}_{2}^{-{ }^{--}}(n=14)$ and their WT $(n=$ 12) mice at the age of 6-7 months. They were single-housed with a plastic tunnel $(5 \mathrm{~cm} \emptyset \times 15 \mathrm{~cm}$ long) added to their cage. This tunnel was used to transport the mouse during testing in order to reduce anxiety levels. A 16-day chronic treatment was launched with melatonin in drinking water. Melatonin $(80 \mathrm{mg})$ progressively dissolved in 1L stirred tap water was freshly prepared and dispatched in opaque bottles every 8 days (O’Neal-Moffit et al., 2015; El Moussaoui and Bendriss, 2014). Since mice are active and drink mostly during the night, our chronic treatment tends to mimic the natural night-time increase in melatonin observed in mice as in humans (Comai and Gobbi, 2014). All mice were tested twice under different treatments in two successive series (Figure 1A): one half received water and the other half received melatonin in the first series, then after a 5-day washout period, the treatment assignment was reversed for the second series. This protocol was designed to reduce the number of mice (3R reduction rule) and it was validated in the first experiment. Mice were tested the last 5 days of each series between 9.00 a.m. and 1.00 p.m. Bottles and mice were weighed at the start and at the end of each 8-day period to calculate daily fluid intake (approximately $0.45 \mathrm{mg} /$ day). This was within the range of doses used in studies reporting a promnestic effect of melatonin in the drinking water of mouse models of AD (Mukda O’Neal-Moffitt et al., 2016; O’Neal-Moffitt et al., 2015).

Object based recognition tasks were performed in an open field ( 92.5 x 92.5 x $35 \mathrm{~cm}$; Ugo Basile, Italy). After a familiarization trial of 8 minutes, mice received a 9 minutes acquisition trial on the next day with two identical objects. After 24 hours, they had a 6-minutes retention trial with one object replaced by a new one in the OR task or with one object moved $30 \mathrm{~cm}$ away from the fixed one in the $O L$ task. A discrimination ratio was calculated as the time spent exploring the novel or displaced object minus time spent exploring the familiar or fixed object/total time spent exploring both objects. The performance is higher than chance level (0) if the mouse detects novelty. Different sets of object were used for each series and the open field and objects were all cleaned with $30 \%$ alcohol between each mouse. We verified that there was no bias due to side, object or series. Two criteria excluded mice for exaggerated neophobic behavior during the retention trial (total exploration below $4 \mathrm{~s}: 1 \mathrm{MT}_{1}^{-1-}, 1 \mathrm{MT}_{2}^{-{ }^{-1}}$ and $1 \mathrm{WT}$ ( $\mathrm{MT}_{2}$ line) mice in the OL task and 1 other WT (MT2 line) mouse in both tasks; strong novel object avoidance with ratio below $-0.45: 1 \mathrm{MT}_{1}^{-/-}$mouse in the OR task).

The light/dark test $(L D)$ was performed to evaluate any possible effect of melatonin on anxiety level because this can be a major confounding factor in OR tasks. The light/dark apparatus was composed of two opaque and transparent PVC boxes $\left(18.5 \times 18.5 \times 15 \mathrm{~cm}^{3}\right)$, connected with an opaque tunnel $(5 \times 5 \times 5.5$ 
$\mathrm{cm}^{3}$ ). Illumination of the transparent box was set at 1000 lux. The mice were placed in the dark box and time spent in the lit compartment was recorded for 5 minutes.

Recognition performance was compared to chance level (0) using a one-sample $t$-test for each group to evaluate novelty detection in OR and OL tasks (reported in the text). A two-way ANOVA for genotype and repeated measures on treatment was applied for recognition performance of $\mathrm{MT}_{1}{ }^{-/}$and $\mathrm{MT}_{2}^{-/-}$mice. We had no expectation on which and how much each receptor would be involved, so between group multiple comparisons were performed with the Student Newman-Keuls test (NK) to gain power in detecting effects. The latter were then analyzed using the more conservative Tuckey HSD to confirm the most robust effects (Sauder and DeMars, 2019; Wilcox, 1987). Recognition performances in the B6 experiment and acquisition exploration were compared using a two-tailed paired t-test. Finally, LD performance was analyzed with a two-way ANOVA on genotype and treatment factors. Effect sizes were calculated as Cohen's d for significant t-tests and eta squared $(\eta 2)$ for significant ANOVAs. Normality and variance equality were assessed by means of the D'Agostino-Pearson normality test and the Levene's test, respectively. Differences were considered significant at $p<0.05$.

\section{RESULTS}

\subsection{Effects of melatonin in C57BL/6J mice}

Chronic melatonin treatment improved OR performance of B6 mice compared to water condition (Figure 1B; paired $t=4.98, d f=11, \mathrm{p}=0.0004, \mathrm{~d}=2.29)$ and chance level $(t=9.61, d f=11, \mathrm{p}<0.0001)$. It also improved OL performance when compared to water condition (Figure $1 \mathrm{C}$; paired $t=3.18, d f=$ $11, \mathrm{p}=0.009, \mathrm{~d}=1,23)$ and chance level $(t=6.76, d f=11, \mathrm{p}<0.0001)$. Melatonin in drinking water did not affect object exploration during acquisition trials in OR (water: $17.9 \pm 1.8 \mathrm{sec}$ and, melatonin: $15.8 \pm 1.8 \mathrm{sec}$; paired $t=1.16, d f=11, \mathrm{p}=0.27$ ) and OL tasks (water: $20.5 \pm 1.9 \mathrm{sec}$ and, melatonin: $21.0 \pm 2.4 \mathrm{sec}$, respectively: paired $t=0.18, d f=11, \mathrm{p}=0.86$ ). Similar results were obtained in the following experiments. The validity of the 2-phase protocol was confirmed in this first experiment (OR main effect of phase: $F_{1,10}=2.13, p=0.17$ and phase $x$ treatment interaction $F_{1,10}=0.39, p=0.55$; OL main effect of phase: $F_{1,10}=0.09, p=0.77$ and phase $x$ treatment interaction $F_{1,10}=1,68, p=0.22$ ). We verified in the following experiments that there was no significant phase effect and interactions with phase.

\subsection{Effects of melatonin on recognition performance in $\mathrm{MT}_{1}{ }^{-/-}$mice}

The melatonin treatment significantly increased OR memory of $\mathrm{MT}_{1}^{---}$mice and their WTs when compared to water condition (treatment $\mathrm{F}_{1,22}=21.44, \mathrm{p}=0.0001$, no genotype or treatment $\mathrm{x}$ genotype interaction) (Figure 1D). Both genotypes performed higher than chance level when treated with melatonin $(t>5.0, d f=11, \mathrm{p}<0.005)$. The significant NK effect of melatonin was confirmed by the 
Tuckey HSD test mainly for WT mice (WT $\mathrm{p}=0.003 ; \mathrm{MT}_{1}^{-/-} \mathrm{p}=0.08$ ). There was significant genotype $\left(F_{1,22}=8.26, p=0.009, \eta^{2}=0.002\right)$ and treatment effects $\left(F_{1,22}=6.78, p=0.016, \eta^{2}=0.49\right)$ on $\mathrm{OL}$ performances, but no treatment $\mathrm{x}$ genotype interaction (Figure 1E). Melatonin barely improved performance in $\mathrm{MT}_{1}^{-{ }^{-}}$mice ( $\mathrm{NK}$ only $\mathrm{MT}_{1}^{-/-} \mathrm{vs} \mathrm{WT}$; vs chance level, $\mathrm{t}=1.33, d f=11, \mathrm{p}=0.21$ ) whereas performance of WTs improved when compared to water condition (NK only) and to chance level ( $t=$ 5.36, $d f=11, \mathrm{p}=0.0002$ ). Thus, only OR performance in $\mathrm{MT}_{1}^{-{ }^{--}}$mice were modestly improved by melatonin.

$\mathrm{MT}_{1}$ deficiency did not affect objects exploration during acquisition (OR: water WT $23.5 \pm 3.6 \mathrm{sec}$, water $\mathrm{MT}_{1}^{-/-} 20.7 \pm 2.0 \mathrm{sec}$; OL: water WT $23.3 \pm 3.0 \mathrm{sec}$, water $\mathrm{MT}_{1}^{-1-} 18.9 \pm 2.7 \mathrm{sec}$; for all comparisons: $t<1.09, d f=22, \mathrm{p}>0.05$ ). The level of anxiety was similar among groups (time in lit box: water WT $114.4 \pm 10.4 \mathrm{sec}$; melatonin WT $117.6 \pm 4.7 \mathrm{sec}$; water $\mathrm{MT}_{1}^{-/-1} 111.3 \pm 5.8 \mathrm{sec}$; melatonin $\mathrm{MT}^{1--} 100.2 \pm 7.4 \mathrm{sec}, \mathrm{F}_{1,21}<2.21, \mathrm{p}>0.05$, no NK significance).

\subsection{Effects of melatonin on recognition performance in $\mathrm{MT}_{2}{ }^{-/}$mice}

$\mathrm{MT}_{2}^{-{ }^{-}-}$mice did not show the increase in OR performance observed in their WTs under melatonin treatment (treatment $F_{1,23}=9.03, p=0.006, \eta^{2}=0.27$; treatment $x$ genotype interaction $F_{1,23}=7.33, p$ $=0.012$; no genotype effect; vs chance level, WT melatonin: $t=6.85, d f=11, \mathrm{p}<0.0001$ and $\mathrm{MT}_{2}^{-{ }^{--}}$ melatonin: $t=2.18, d f=13, \mathrm{p}=0.05$; Figure $1 \mathrm{~F}$ ). The melatonin effect detected in WT (NK) was confirmed by the Tuckey HSD test (WT water vs melatonin: $\mathrm{p}=0.005$; melatonin WT vs $\mathrm{MT}_{2}^{-1-}$ : $\mathrm{P}=0.0504$; $\mathrm{MT}^{-{ }_{-}}$water vs melatonin: $\left.\mathrm{p}=0.996\right)$. Melatonin improved OL performance to a greater extent in WT mice than in $\mathrm{MT}_{2}^{-{ }^{--}}$mice as confirmed by the Tuckey HSD test (water vs melatonin in WT only $\mathrm{p}=0.049$ and melatonin WT vs $\mathrm{MT}_{2}^{-{ }^{-}} \mathrm{p}=0.04$; treatment $\mathrm{F}_{1,21}=5.66, \mathrm{p}=0.027, \eta^{2}=0.19$; genotype $\mathrm{F}_{1,21}=5.08, \mathrm{p}=0.035, \eta^{2}=0.09$; no treatment $\mathrm{x}$ genotype interaction; vs chance level, melatonin WT and $\mathrm{MT}_{2}^{---}: t \geq 3.3, d f=9,13, \mathrm{p}<0.006$ ) (Figure $1 \mathrm{G}$ ). Thus, $\mathrm{MT}_{2}$ deficiency affected the beneficial effect of melatonin in the OR task and to a lesser extent in the OL task.

$\mathrm{MT}_{2}{ }^{-{ }^{-}}$deficiency did not affect object exploration during acquisition trials (OR task: water WT $19.3 \pm$ $1.8 \mathrm{sec}$, water $\mathrm{MT}_{2}{ }^{-/} 18.4 \pm 1.4 \mathrm{sec}$; OL task: water WT $17.0 \pm 1.8 \mathrm{sec}$, water $\mathrm{MT}_{2}{ }^{-/} 16.8 \pm 1.8 \mathrm{sec}$; for all comparisons: $t<0.17, d f=21 / 23, \mathrm{p}>0.05$ ). Anxiety level was similar among groups (time in lit box: water WT: $116.8 \pm 11.0 \mathrm{sec}$; melatonin WT: $116.8 \pm 12.5 \mathrm{sec}$; water $\mathrm{MT}_{2}{ }^{-1-}: 117.7 \pm 5.7 \mathrm{sec}$; melatonin $\mathrm{MT}_{2}^{-{ }^{-/}}: 110.1 \pm 7.7 \mathrm{sec}, \mathrm{F}_{1,22}<0.16, \mathrm{p}>0.05$, no NK significance).

\section{DISCUSSION}

Our aim was to explore the role of $\mathrm{MT}_{1}$ and $\mathrm{MT}_{2}$ in recognition memory using $\mathrm{MT}_{1}{ }^{-/}$and $\mathrm{MT}_{2}{ }^{-{ }_{-}}$deficient mouse lines on a B6 background. The key result is that melatonin lost its memory improving effect on OR performance in $\mathrm{MT}_{2}^{-{ }^{--}}$mice, and to a lesser extent on OL performance in both $\mathrm{MT}_{1}{ }^{-{ }_{-}}$and $\mathrm{MT}_{2}{ }^{-{ }_{-}}$ 
mice. These results are in favor of a strong involvement of $\mathrm{MT}_{2}$ in the effects of melatonin on long-term OR, whereas both receptors seem to have a less critical role in OL memory.

Handling, treatments and genetic manipulations can affect memory performance in object-based recognition tasks through changes in anxiety levels or motivation to explore novelty (Mathis, 2019). It is noteworthy that we handled our mice by tunnel to reduce anxiety levels throughout the experiment. Here, we show that chronic melatonin treatment and melatonin receptor deletion did not affect novel objects exploration and anxiety levels. A lack of effect on locomotion, object exploration and anxiety levels during the light phase has also been reported in other studies using chronic melatonin treatment and other $\mathrm{MT}_{1}$ and/or $\mathrm{MT}_{2}$ deficient mouse lines (Comai et al., 2020; Olcese et al., 2009; O’Neal-Moffitt et al., 2014, 2015). The lack of effect on object exploration and anxiety levels strongly suggests that the chronic melatonin treatment promoted mechanisms underlying long-term recognition memory. Although mice had continuous access to melatonin, it was most likely ingested during the night when mice are the most active and feed (Possidente and Birnbaum, 1979). Given our interest in melatonin receptors as potential targets to treat memory disorders, mice were tested during day light when memory performance must be improved in humans. However, the limit of this method is that we cannot conclude on which stage of information processing benefited from the treatment. Previous studies using single peripheral injection of melatonin $(2.5-50 \mathrm{mg} / \mathrm{kg})$ indicate that melatonin can improve both acquisition/consolidation and recall processes (Bertaina-Anglade et al., 2011; He et al., 2013).

The differential involvement of $\mathrm{MT}_{1}$ and $\mathrm{MT}_{2}$ could be related to a direct action on different sets of brain structures involved in long-term recognition memory. Long-lasting OR memory requires a brain network which includes hippocampal CA1, medial prefrontal cortex and perirhinal cortex (Cohen et al., 2013; Tanimizu et al., 2018). CA1 and prefrontal regions are also critically involved in the formation of long-lasting OL memory, but not perirhinal cortex (Barker et al., 2007; Tuscher et al., 2018). $\mathrm{MT}_{1}$ and $\mathrm{MT}_{2}$ are expressed in all these hippocampal and cortical regions, except in perirhinal cortex for $\mathrm{MT}_{1}$ (Klosen et al., 2019; Lacoste et al., 2015; Musshoff et al., 2002). Thus, brain distribution of the $\mathrm{MT}_{2}$ is coherent with a role in long lasting OL and OR memories. On the other hand, the lack of $\mathrm{MT}_{1}$ in perirhinal cortex may explain negative results in the OR task, whereas its expression in CA1 and prefrontal cortex regions is in accordance with an involvement in long-term OL memory. Alternatively, $\mathrm{MT}_{1}$ and $\mathrm{MT}_{2}$ could have played an indirect effect on memory consolidation through their implication in the regulation of sleep episodes and/or architecture (Gobbi and Comai, 2019). An increase in NREM sleep due to $\mathrm{MT}_{2}$ activation may favor OL memory consolidation (Binder et al., 2012). On the other hand, sleep fragmentation has a deleterious effect on OR memory consolidation (Rolls et al., 2011). In depth exploration of these hypotheses would certainly clarify the role of $\mathrm{MT}_{1}$ and $\mathrm{MT}_{2}$ in sleep features that modulate each form of recognition memory.

Our study suggests that $\mathrm{MT}_{2}$ is required for the beneficial effect of melatonin on long-term OR memory, whereas both $\mathrm{MT}_{1}$ and $\mathrm{MT}_{2}$ activation seem to modulate long-term OL memory. These results should encourage further research to elucidate the respective roles of these two receptors in mediating the 
regulating effect of melatonin on memory. It would be worth combining the use of single receptor deficient mice and selective agonists of each receptor. Understanding the contribution of $\mathrm{MT}_{1}$ and $\mathrm{MT}_{2}$ to recognition memory process is crucial in designing melatonin-based drugs for the treatment of pathologies associated to cognitive disorders such as Alzheimer's disease.

\section{FUNDING SOURCES}

This work was funded by an Idex 2018 postdoctoral award of the University of Strasbourg and the Centre National de la Recherche Scientifique (CNRS). These funding sources had no involvement in any aspect of the study design, collection, analysis and interpretation of data, writing of the report and decision to submit the article for publication.

\section{CONTRIBUTORS}

Cristiana Pistono: data analyses and and presentation, manuscript writing. Amandine Zimmermann, Chloé Morel, Karine Herbeaux, Céline Héraud and Stéphanie Dumont-Kientzy: technical support and data collection. Marie-Paule Felder-Schmittbuhl: creation and breeding of receptor deficient mice, critical revision of the manuscript. Paul Pevet: conceptualization, critical revision of the manuscript. Chantal Mathis: conceptualization, funding acquisition, writing review \& editing.

\section{DECLARATION OF COMPETING INTEREST}

The authors declare that they have no competing financial interests in relation to the work described.

\section{ACKNOWLEDGEMENTS}

The authors thank Olivier Bildstein and Georges Egesi for taking care of the mice.

\section{REFERENCES}

Barker, G.R.I., Bird, F., Alexander, V., Warburton, E.C., 2007. Recognition Memory for Objects, Place, and Temporal Order: A Disconnection Analysis of the Role of the Medial Prefrontal Cortex and Perirhinal Cortex. J. Neurosci. 27, 2948-2957. https://doi.org/10.1523/JNEUROSCI.528906.2007

Bertaina-Anglade, V., Drieu-La-Rochelle, C., Mocaër, E., Seguin, L., 2011. Memory facilitating effects of agomelatine in the novel object recognition memory paradigm in the rat. Pharmacol. Biochem. Behav. 98, 511-7. https://doi.org/10.1016/j.pbb.2011.02.015

Binder, S., Baier, P.C., Mölle, M., Inostroza, M., Born, J., Marshall, L., 2012. Sleep enhances memory consolidation in the hippocampus-dependent object-place recognition task in rats. Neurobiol. Learn. Mem. 97, 213-219. https://doi.org/10.1016/j.nlm.2011.12.004

Cohen, S.J., Munchow, A.H., Rios, L.M., Zhang, G., Asgeirsdóttir, H.N., Stackman, R.W., 2013. The rodent hippocampus is essential for nonspatial object memory. Curr. Biol. 23, 1685-90. 
https://doi.org/10.1016/j.cub.2013.07.002

Comai, S., De Gregorio, D., Posa, L., Ochoa-Sanchez, R., Bedini, A., Gobbi, G., 2020. Dysfunction of serotonergic activity and emotional responses across the light-dark cycle in mice lacking melatonin MT 2 receptors. J. Pineal Res. https://doi.org/10.1111/jpi.12653

Comai, S., Gobbi, G., 2014. Unveiling the role of melatonin MT2 receptors in sleep, anxiety and other neuropsychiatric diseases: a novel target in psychopharmacology. J. Psychiatry Neurosci. 39, 621. https://doi.org/10.1503/jpn.130009

Dubocovich, M.L., Hudson, R.L., Sumaya, I.C., Masana, M.I., Manna, E., 2005. Effect of MT1 melatonin receptor deletion on melatonin-mediated phase shift of circadian rhythms in the C57BL/6 mouse. J. Pineal Res. 39, 113-20. https://doi.org/10.1111/j.1600-079X.2005.00230.x

Najoua El Moussaoui, Abdenbi Bendriss. 2014 The Influence of Storage Conditions on Melatonin. International Journal of Engineering Research \& Technology 3(3):2243-2246

Gobbi, G., Comai, S., 2019. Differential Function of Melatonin MT1 and MT2 Receptors in REM and NREM Sleep. Front. Endocrinol. (Lausanne). 10, 87. https://doi.org/10.3389/fendo.2019.00087

He, P., Ouyang, X., Zhou, S., Yin, W., Tang, C., Laudon, M., Tian, S., 2013. A novel melatonin agonist Neu-P11 facilitates memory performance and improves cognitive impairment in a rat model of Alzheimer' disease. Horm. Behav. 64, 1-7. https://doi.org/10.1016/j.yhbeh.2013.04.009

Jean-Louis, G., von Gizycki, H., Zizi, F., 1998. Melatonin effects on sleep, mood, and cognition in elderly with mild cognitive impairment. J. Pineal Res. 25, 177-83. https://doi.org/10.1111/j.1600079x.1998.tb00557.x

Klosen, P., Lapmanee, S., Schuster, C., Guardiola, B., Hicks, D., Pevet, P., Felder-Schmittbuhl, M.P., 2019. MT1 and MT2 melatonin receptors are expressed in nonoverlapping neuronal populations. J. Pineal Res. e12575. https://doi.org/10.1111/jpi.12575

Lacoste, B., Angeloni, D., Dominguez-Lopez, S., Calderoni, S., Mauro, A., Fraschini, F., Descarries, L., Gobbi, G., 2015. Anatomical and cellular localization of melatonin MT1 and MT2 receptors in the adult rat brain. J. Pineal Res. 58, 397-417. https://doi.org/10.1111/jpi.12224

Mathis, C., 2018. The Value of the Object Recognition Paradigm in Investigating Animal Models of Alzheimer's Disease, in: Handbook of Object Novelty Recognition. pp. 307-330. https://doi.org/10.1016/B978-0-12-812012-5.00021-5

Mukda, S., Panmanee, J., Boontem, P., Govitrapong, P., 2016. Melatonin administration reverses the alteration of amyloid precursor protein-cleaving secretases expression in aged mouse hippocampus. Neurosci. Lett. 621, 39-46. https://doi.org/10.1016/j.neulet.2016.04.013

Musshoff, U., Riewenherm, D., Berger, E., Fauteck, J.-D., Speckmann, E.-J., 2002. Melatonin receptors in rat hippocampus: molecular and functional investigations. Hippocampus 12, 165-173. https://doi.org/10.1002/hipo.1105

Olcese JM, Cao C, Mori T, et al. Protection against cognitive deficits and markers of neurodegeneration by long-term oral administration of melatonin in a transgenic model of Alzheimer disease. J Pineal 
Res. 2009;47(1):82-96. doi:10.1111/j.1600-079X.2009.00692.x

O’Neal-Moffitt, G., Delic, V., Bradshaw, P.C., Olcese, J., 2015. Prophylactic melatonin significantly reduces Alzheimer's neuropathology and associated cognitive deficits independent of antioxidant pathways in A $\beta P P($ swe)/PS1 mice. Mol. Neurodegener. 10, 27. https://doi.org/10.1186/s13024015-0027-6

O’Neal-Moffitt, G., Pilli, J., Kumar, S.S., Olcese, J., 2014. Genetic deletion of $\mathrm{MT}_{1} / \mathrm{MT}_{2}$ melatonin receptors enhances murine cognitive and motor performance. Neuroscience 277, 506-21. https://doi.org/10.1016/j.neuroscience.2014.07.018

Peck, J.S., LeGoff, D.B., Ahmed, I., Goebert, D., 2004. Cognitive effects of exogenous melatonin administration in elderly persons: a pilot study. Am. J. Geriatr. Psychiatry 12, 432-6. https://doi.org/10.1176/appi.ajgp.12.4.432

Possidente, B., Birnbaum, S., 1979. Circadian rhythms for food and water consumption in the mouse, Mus musculus. Physiol. Behav. 22, 657-60. https://doi.org/10.1016/0031-9384(79)90226-9

Rolls, A., Colas, D., Adamantidis, A., Carter, M., Lanre-Amos, T., Heller, H.C., de Lecea, L., 2011. Optogenetic disruption of sleep continuity impairs memory consolidation. Proc. Natl. Acad. Sci. U. S. A. 108, 13305-10. https://doi.org/10.1073/pnas.1015633108

Sauder, D.C., DeMars, C.E., 2019. An Updated Recommendation for Multiple Comparisons. Adv. Methods Pract. Psychol. Sci. 2, 26-44. https://doi.org/10.1177/2515245918808784

Shukla, M., Govitrapong, P., Boontem, P., Reiter, R.J., Satayavivad, J., 2017. Mechanisms of Melatonin in Alleviating Alzheimer's Disease. Curr. Neuropharmacol. 15, 1010-1031. https://doi.org/10.2174/1570159X15666170313123454

Tanimizu, T., Kono, K., Kida, S., 2018. Brain networks activated to form object recognition memory. Brain Res. Bull. 141, 27-34. https://doi.org/10.1016/j.brainresbull.2017.05.017

Tuscher, J.J., Taxier, L.R., Fortress, A.M., Frick, K.M., 2018. Chemogenetic inactivation of the dorsal hippocampus and medial prefrontal cortex, individually and concurrently, impairs object recognition and spatial memory consolidation in female mice. Neurobiol. Learn. Mem. 156, $103-$ 116. https://doi.org/10.1016/j.nlm.2018.11.002

Wilcox, R.R., 1987. New Designs in Analysis of Variance. Annu. Rev. Psychol. 38, 29-60. https://doi.org/10.1146/annurev.ps.38.020187.000333

\section{FIGURE LEGENDS}

Figure 1. Effect of a chronic treatment of melatonin on recognition memories. A) Schema showing the testing schedule used for the whole study. B) Melatonin significantly improved OR performance and C) OL performance in C57BL/6J mice ( $\mathrm{n}=12)$. Paired $t$ test, melatonin- $v s$ water-treated mice: \# $\mathrm{p}<0.05$, $\# \# \mathrm{p}<0.01$, \#\#\# $\mathrm{p}<0.001$. D) Melatonin improved OR performance in $\mathrm{WT}$ and $\mathrm{MT}_{1}^{-{ }^{--}}$mice 
( $\mathrm{n}=12 /$ group), E) as well as in the OL task for $\mathrm{WT}$, but not $\mathrm{MT}_{1}{ }^{-/-}$mice ( $\mathrm{n}=12 /$ group). Melatonin improved OR performance in WT mice $(\mathrm{n}=11)$, but not in $\mathrm{MT}_{2}^{-{ }^{-}}$mice $\left.(\mathrm{n}=14), \mathrm{D}\right)$ as well as in the OL task for WT mice $(\mathrm{n}=10)$, but not $\mathrm{MT}_{2}{ }^{-1-}$ mice $(\mathrm{n}=13)$. Post-hoc NK : melatonin- vs water-treated mice: $\# \mathrm{p}<0.05, \# \# \mathrm{p}<0.01, \# \# \mathrm{p}<0.001$. Significances confirmed by the Tukey HSD test are indicated in the text. 
A

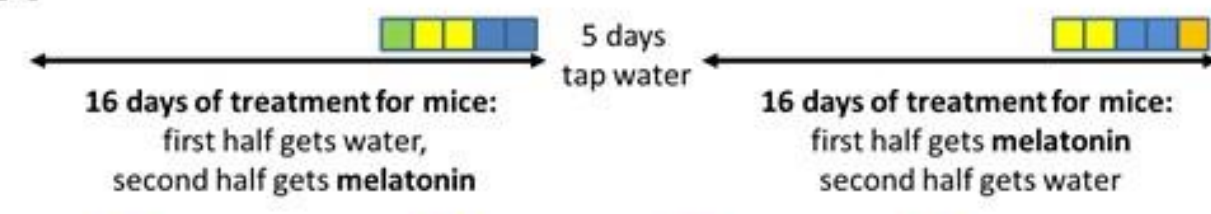

Habituation $\square$ OR task $\quad \square$ OL task $\quad \square$ light dark test

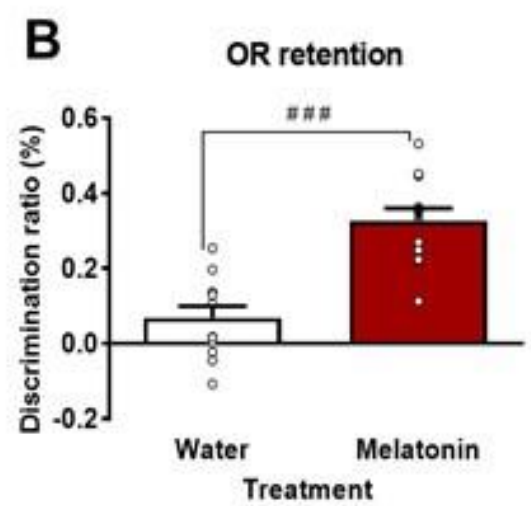

D

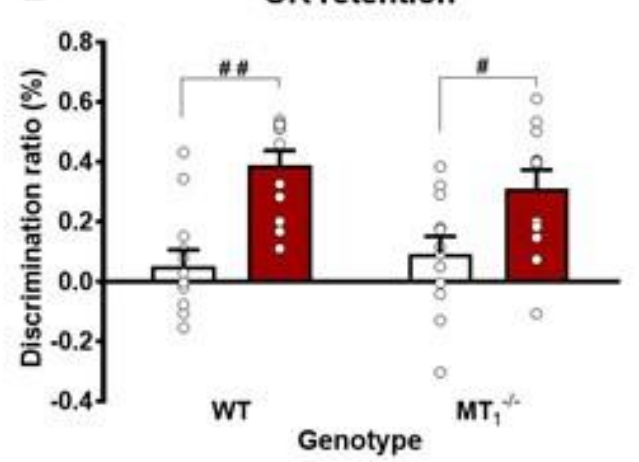

F

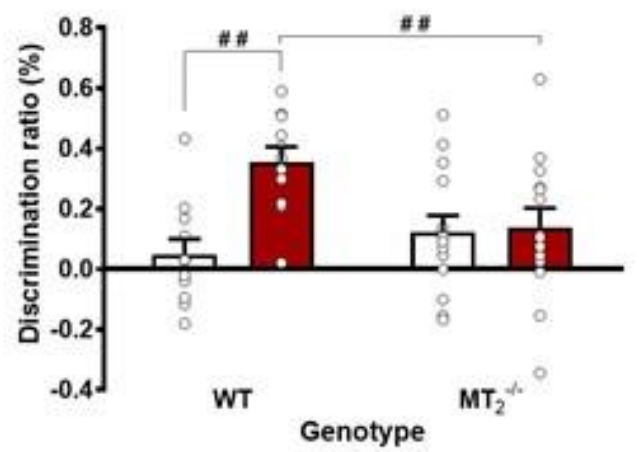

C

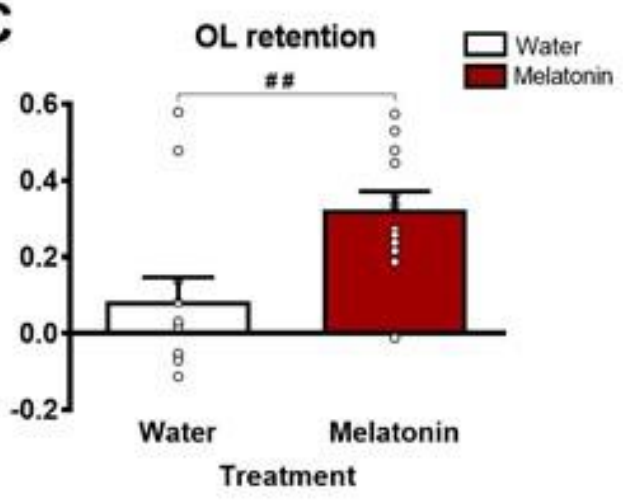

E

OL retention

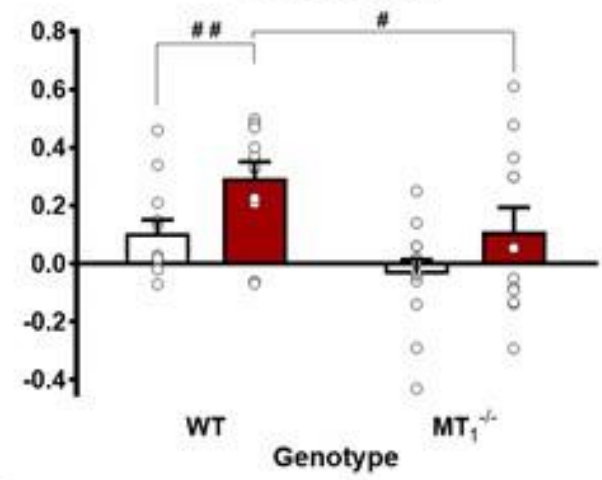

G

OL retention

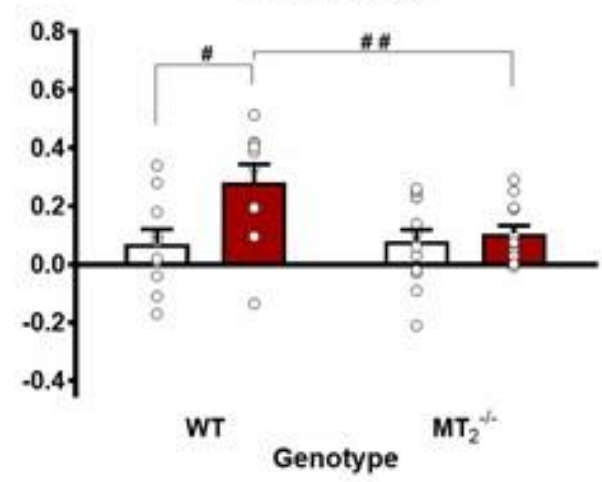




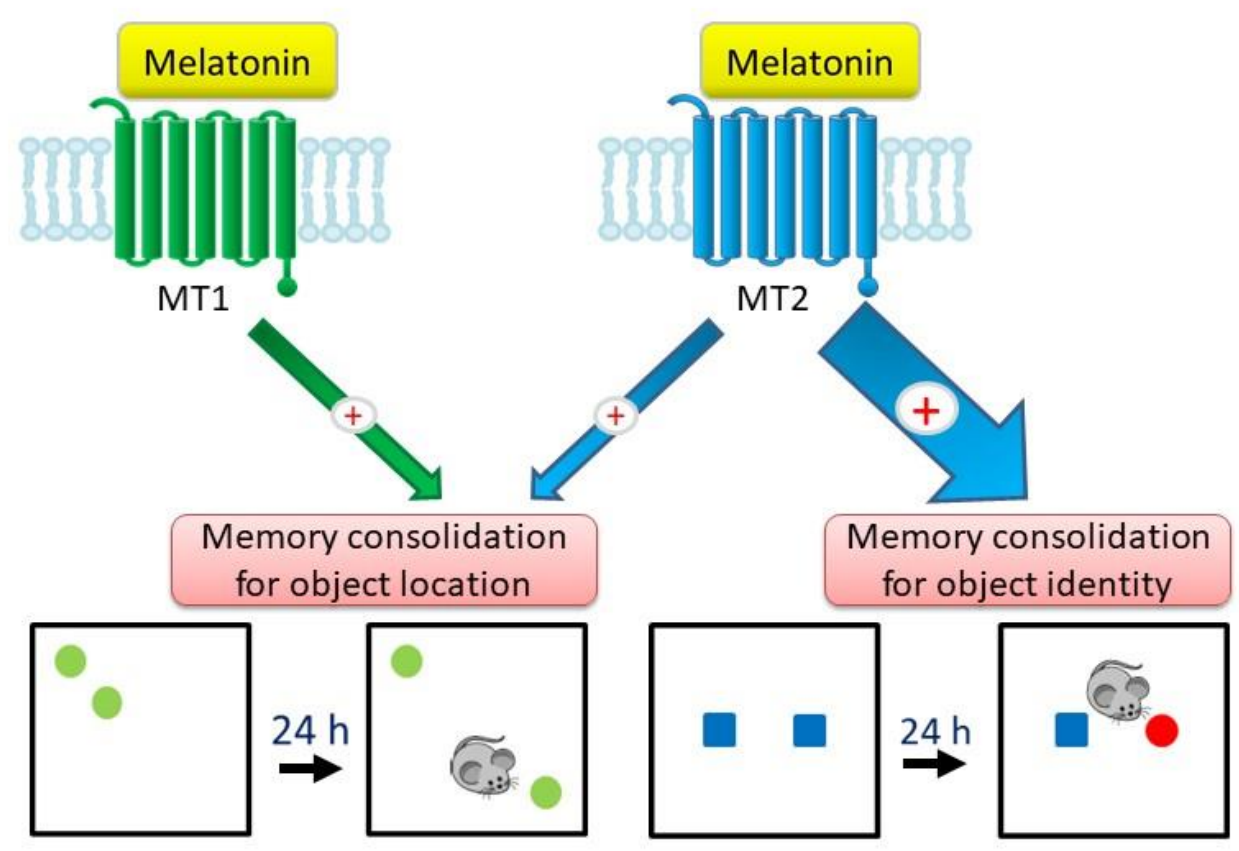

Graphical abstract

\section{HIGHLIGHTS}

$\square$ Melatonin improves performance in long-term object recognition and location tasks

MT2 is required for the effect of melatonin on long-term object recognition memory

Both MT1 and MT2 activation seems to modulate long-term object location memory 